\title{
Consumer attitudes to injurious pecking in free range egg production
}

Article

Accepted Version

Bennett, R. M.., Jones, P. J., Nicol, C. J., Tranter, R. B. and Weeks, C. A. (2016) Consumer attitudes to injurious pecking in free range egg production. Animal Welfare, 25 (1). pp. 91100. ISSN 0962-7286 doi:

https://doi.org/10.7120/09627286.25.1.091 Available at https://centaur.reading.ac.uk/41574/

It is advisable to refer to the publisher's version if you intend to cite from the work. See Guidance on citing.

To link to this article DOI: http://dx.doi.org/10.7120/09627286.25.1.091

Publisher: UFAW

All outputs in CentAUR are protected by Intellectual Property Rights law, including copyright law. Copyright and IPR is retained by the creators or other copyright holders. Terms and conditions for use of this material are defined in the End User Agreement.

\section{www.reading.ac.uk/centaur}

\section{CentAUR}

Central Archive at the University of Reading 
Reading's research outputs online 
1 Consumer attitudes to injurious pecking in free range egg production

2

\section{Introduction}

4 Injurious pecking (IP) is a behaviour found in a majority of egg-laying flocks in the United

5 Kingdom (UK) and beyond. Rodenburg et al (2013) and Nicol et al (2013) provide extensive

6 reviews of both the extent of IP and its prevention and control in commercial systems. IP

7 encompasses severe feather pecking and cannibalistic (often vent) pecking, frequently

8 resulting in pain, skin damage, plumage loss and significant economic losses to the industry.

9 It is particularly prevalent in non-cage systems, where a pecking bird has access to a far 10 greater number of victims than it would in a cage system (Keeling and Jensen 1995). In addition, the problem is harder to manage in non-cage systems, since perpetrators cannot easily be identified (e.g. Gunnarsson et al 1999; Green et al 2000; Sherwin et al 2010). IP can start during the rearing period, though plumage damage is not usually recognised, as birds moult several times before lay. The problem increases when birds are brought into lay, possibly due to changes in hormone levels (Hughes 1973; Norgaard-Nielsen et al 1993).

Careful management is essential during rearing to ensure a smooth transition from rear to lay (McKeegan \& Savory 1999; Nicol et al 1999; Pötzsch et al 2001).

The estimated prevalence of IP depends on the method used to measure it in poultry populations. One method focuses on the proportion of flocks affected, regardless of severity. Using this measure, farmer reports have estimated the proportion of flocks experiencing IP at $62 \%$ in Sweden (Gunnarrson et al 1999), 37.5\% in Switzerland (Huber-Eicher 1999) and 47\% in the UK (Green et al 2000). Lambton et al (2010) when observing 111 UK farms found severe feather pecking on $85.6 \%$ of farms at 40 weeks. However, these estimates take no account of the proportion of birds within a flock that might be affected, or the degree of 
severity of pecking. Both phenomena are reviewed by Nicol et al (2013). Rates of severe

27

feather pecking have been recorded at 1.15 pecks/bird/h (Nicol et al 1999) or 1.22

bouts/bird/h (Lambton et al 2010). In all cases, these mean figures mask considerable interfarm variation.

The economic consequences of IP can be substantial but calculating them is complex as many factors contribute to losses (Nicol et al 2013). Reduced plumage cover is linked with reduced feed conversion efficiency (Tauson \& Svensson 1980; Peguri \& Coon 1993). Severely feather pecked (bald) chickens need up to $40 \%$ more feed to maintain body temperature (Blokhuis et al 2007) and the birds are less efficient at converting food into egg mass. Outbreaks of feather pecking and cannibalism also reduce overall egg production because of the associated rise in mortality (Hughes \& Duncan 1972; Green et al 2000; El-Lethey et al 2000; Huber-Eicher \& Sebo 2001). Farmers tend to attribute a low rate of mortality to IP (Green et al 2000; Pötzsch et al 2001), much lower than the real proportion. IP is, in fact, a principal cause of mortality in non-cage systems (Rodenburg et al 2008; Fossum et al 2009; Sherwin et al 2010), which in many surveys is at significantly higher levels than in cage systems and may exceed 20\% (Blokhuis 2005; Blokhuis et al 2007; Rodenburg et al 2013; Weeks et al 2012).

Worldwide, beak trimming conducted by either the infra-red (IR) or hot blade (HB) technique is the primary method used by the industry to limit the damage caused by IP (Dennis et al 2009). In adult birds, HB beak-trimming has been shown to reduce cannibalism-related mortality in floor pens (Damme 1999) and reduce plumage damage (Staack et al 2007). Beak trimmed birds also tend to eat 'more efficiently', performing less exploratory pecking and improving their food conversion ratio. However, it is difficult to distinguish whether the 
commonly-observed behavioural changes observed to occur after trimming (reduced pecking behaviour and activity (Gentle et al 1990; Craig \& Lee 1990)) indicate pain or changes in beak sensitivity (Hughes \& Gentle 1995).

A number of countries have or are considering implementing a ban on beak trimming. The UK Government has set a review date of 2015 with a view to banning beak trimming in 2016 (Defra, 2010).

A ban on beak-trimming requires that the hens' propensity to peck other hens can be controlled or reduced by changes to housing, management, or other practices that maintain or improve bird welfare. The study reported here was part of a larger study which examined the effectiveness of evidence-based management strategies in reducing IP in practice. One hundred flocks on 63 farms were recruited for the study, of which 53 trialled suggested changes in management to control IP. Both treatment and control flocks were already employing a variety of the 46 possible management strategies, but farms enrolled as treatment farms added additional management strategies to their flock management at an early stage in the study. The uptake of new management strategies was encouraged by modest financial or practical assistance in obtaining some of the materials required (e.g. pecking blocks, starter packs of compressed wood pellets etc). The average cost of implementing the management strategies on the treatment farms was approximately 5 pence per bird $(0.016 \mathrm{p}$ egg assuming a mean of 25 dozen eggs/bird/year). Some of the costs were one-off improvements that would remain in place for many subsequent flocks such as provision of artificial shelters or planting trees, whereas others such as maintaining friable litter require ongoing labour and substrate provision (for details see: www.featherwel.org). Lambton et al (2013) describe in more detail this project and its findings. 
In the October quarter of 2011, 44.1 per cent of UK egg packers' throughput was from free range units, which make up the overwhelming majority of UK non-cage systems (Defra 2014). Almost all of this free range production is to Freedom Food Standards which specify stocking rates and limit colony size to 4,000 birds (maximum flock size of 16,000). The principal finding of the study was that the more of the 46 management strategies that were employed, plumage damage, incidence of feather pecking behaviour and likelihood of vent pecking were all significantly reduced alongside a reduction in levels of mortality at 40 weeks of age (Lambton et al 2013). Thus, the premise that IP can be reduced by altered practices, some of which have a cost, was substantiated.

A report by IGD (2011) found that nearly half of UK consumers surveyed stated that animal welfare was either very important, or extremely important, to them. There are a number of studies in the literature that report that consumers are concerned about hen welfare in particular, although not about IP specifically. For example, at the EU level, the Eurobarometer (2007) survey reported that $58 \%$ of citizens across 25 member states thought that hen welfare in their countries was either 'very' or 'fairly' bad. In Great Britain, Mayfield et al (2007) found that $64 \%$ of consumers thought the treatment of hens was very important (only 9\% thought it not important) although 56\% thought that welfare conditions for hens were poor.

In the sections that follow, we present the results of the above project's consumer survey where consumer attitudes to free range egg production are detailed together with the calculation of the price premium consumers said they would be prepared to pay to help reduce IP in free range systems. After discussion of the results, some conclusions are drawn and the implications for animal welfare policy are considered. 
Methodology

A focus group of eight consumers was carried out to help inform the design of the consumer postal survey. The focus group was stratified to ensure participants came from a mix of socio-economic backgrounds. The following issues were explored with focus group participants: consumer beliefs concerning the welfare of hens in free range laying systems; current knowledge of IP; attitudes to IP and the welfare of hens after a full briefing about IP; and attitudes to the potentially higher costs of eggs resulting from the introduction of on-farm measures leading to reduced levels of IP. Beak trimming was not mentioned as it was regarded as a separate welfare issue.

Findings from the consumer focus group were used to help inform design of a questionnaire which was then trialled in a pilot exercise with 10 egg consumers. Following this exercise, the A4-size, two-page questionnaire was revised (see Appendix 1). It consisted of four sections designed to collect information, in order, on:

- the demographics of the respondent and their household;

The amended questionnaire was sent to a sample of 1776 consumers stratified by geographical location and socio-economic characteristics such as age, sex, income and type of accommodation. This was undertaken to try to ensure the sample was representative of all

124 GB consumers with particular emphasis on those socio-economic characteristics that were thought, a priori, to affect egg purchasing behaviour. The sample was purchased from the 
126 Yell.com telephone database for GB and the questionnaires, together with a covering letter,

127 were sent out on Wednesday 20 July 2011 with a reply-paid envelope for their return. A reminder letter with a further copy of the questionnaire was sent out on Wednesday 17 August 2011 and a second reminder letter was sent out on Wednesday 14 September 2011; a response rate of nearly $15 \%$ was obtained with 257 questionnaires returned. Response rates to surveys can vary greatly depending on a host of factors. Kaplowitz et al (2004) report an average response rate of $13 \%$ for mail surveys suggesting that $15 \%$ is not unreasonable. Alternative survey administration methods, such as in person, by telephone and on the internet were considered (see Marsden and Wright, 2010 for a comprehensive description). The first was thought to be far too costly, the second was costlier than using mail and also it was felt that respondents needed the wtp part of the questionnaire in front of them to be able to answer the questions (although a mixed approach using post and telephone would have been possible). The third method, using the internet, was thought likely to achieve a low response rate for a survey of this kind.

To check the representativeness of the respondents, comparisons were made with the National Population Census (ONS, 2013). This revealed that they were representative in terms of age, education and employment status, but there was a significant difference in gender balance, with $24 \%$ more women responding to the survey than would be expected. This is likely to be because the main food purchaser in households would be the one who tended to complete the questionnaire. Probably, for the same reason, there was a slight under-representation amongst respondents of the very youngest consumers.

The contingent valuation (CV) technique was used to elicit consumers' wtp to help poultry farmers ensure that hens do not suffer from IP. The CV approach (see Mitchell and Carson, 
151 1989) was used because, in the context of this study, it was considered more appropriate and easier (i.e. less cognitively difficult) for respondents to understand and respond to in a mail survey compared to stated choice approaches (see Louviere et al 2000). Prior to the bid questions, some briefing information was offered. First, the phenomenon of IP was described and details given of management approaches that might be adopted to control it (see Appendix 1). It was also pointed out that these control measures would result in increased costs of production for the farmer. Second, respondents were reminded of the prevailing price context for free-range egg purchases in an attempt to 'ground' their wtp responses in reality (wtp studies often remind respondents of their limited budget or provide a 'cheap talk' how consumers compare prices when food shopping).

Consumers were asked whether they would be willing to pay a specified amount of money as an extra payment on top of what they currently pay per half dozen for free range eggs to help poultry farmers ensure that hens do not suffer from injurious pecking. One of eight different initial bid levels (ranging from 2 pence to 16 pence) for six free range medium-sized eggs were randomly allocated to those sampled. If they were prepared to accept the initial bid (they were given the option of saying 'yes', 'no' or 'no opinion'), the next given bid level provided was $50 \%$ higher. If the first bid was rejected, respondents were then offered a bid at

171 a level of half the initial bid level. This technique is known as the double-bounded dichotomous choice wtp elicitation method and has been recommended for use in CV studies (Hanemann et al, 1991). Immediately after the bid questions, respondents were then asked to describe briefly the reasoning behind their answers to the bid questions; this practice is often called 'debriefing'. 
177 Several methods could have been used to estimate wtp using the data. The approach used in this case was an Interval Maximum Likelihood Logistic Regression (SAS, PROC LOGISTIC) which predicted consumer response to BID (the highest accepted bid value) based on a number of determining variables, including various socio-economic characteristics of the respondent, attitudinal responses to questions about egg production and the opening bid level. The total usable sample size was 250 , after deleting non-responses to the wtp question. However, a relatively large number (190) of the observations had randomly occurring missing values, usually just one, or a small number, particularly in the attitudinal questions, resulting in the exclusion of these observations from the Logistic Regression. Thus it was decided that remedial action was necessary to recover and use some of the 'lost' observations.

For this purpose, a principled multiple imputation (MI) method was used to replace missing values (SAS, PROC MI) from the attitudinal questions. Several MI approaches are available (see Rubin 1987) but, in this case, the approach adopted was the Markov Chain Monte Carlo (MCMC) method, as this is regarded as the most appropriate method for datasets with arbitrary missing data patterns compared to any other method (Schafer 1997). MCMC draws a random sample of values to replace missing values from the available distribution for each variable. This process allows for the generation of valid statistical inferences that properly reflect the uncertainty due to missing values - for example, confidence intervals with the correct probability coverage. This also allows standard statistical procedures for complete data analysis to be used with the filled-in data set. As a result of this exercise, a useable sample of 193 respondents was obtained. 
Various techniques could have been employed to estimate wtp but the method employed in

202

203

204

205

206

207

208

209

210

211

212

213

214

215

216

217

218

219

220

221

222

223

224

225 this case was Maximum Likelihood Estimation, after Cameron (1988) and extended by Hanemann et al (1991) and employed by Bennett and Blaney (2003) to estimate consumers' wtp to improve hen welfare via legislation to ban battery cages.

By this approach, individual i has an implicit (unobserved) wtp, for a pack of 6 eggs

produced to higher welfare standards, given by:

(1) $\quad \mathrm{wtp}_{\mathrm{i}}=\underline{x}_{\mathrm{i}} \underline{\mathrm{b}}+\mathrm{s} \mathrm{u}_{\mathrm{i}}$

where:

$\mathrm{wtp}_{\mathrm{i}}$ is the individual's true, but incompletely observed, willingness to pay

$\underline{\mathrm{X}}_{\mathrm{i}}{ }^{\prime}$ is a vector of explanatory factors which can be observed,

$\mathrm{u}_{\mathrm{i}}$ is a symmetric random error with zero mean and unit variance that arises from the unobserved factors about i's wtp, and

$\underline{b}$ is a vector and s a scalar to be estimated.

Each respondent was asked whether they were willing to pay a randomly assigned amount (B

i). The probability of observing a positive response to this wtp question is:

(2)

$$
\operatorname{Pr}(\text { Yes })=\operatorname{Pr}\left(u_{i}<-B_{i} / s+\underline{x}_{i}^{\prime} \underline{b} / s\right) \text {. }
$$

Alternatively, this probability can be written as:

$$
\operatorname{Pr}(\text { Yes })=F\left(\text { c B }{ }_{i}+\underline{d}^{\prime} \underline{x}_{i}\right),
$$


227 where: $\mathrm{c}=-1 / \mathrm{s}$ and $\underline{\mathrm{d}}=\underline{\mathrm{b}} / \mathrm{s} . \mathrm{F}()$ is the cumulative distribution function of $\mathrm{u}_{\mathrm{i}}$ and its 228 assumed distribution determines the type of binary choice model used. The use of a varying 229 bid level enables the identification of the scale of the wtp relationship and so the bid $\left(\mathrm{B}_{\mathrm{i}}\right)$ is 230 included amongst the set of explanatory variables $\left(\underline{x}_{i}\right)$ in the binary choice model. The 231 coefficients obtained from the binary choice model are then used to identify the parameters in 232 Equation (1). The estimated parameters in the binary choice model are $\mathrm{c}$ and $\underline{\mathrm{d}}$ ' and thus the

233

(4)

$$
\underline{\mathrm{b}^{\prime}}=-\underline{\mathrm{d}}^{\prime} / \mathrm{c}
$$

$$
\mathrm{s}=-1 / \mathrm{c}
$$

Once the coefficients of the explanatory variables were obtained from the model, it was then possible to estimate wtp. In this case, maximum likelihood estimation procedures were used, specifying a logit model (assuming a standard logistic distribution function) and using standard procedures available in the software package of the SAS Institute Inc. of Cary, California.

A complete list of all variables used in the Logistic Regression analysis is provided in Appendix 2. The socio-economic variables were selected on the basis that, in past studies, they had proved to be good indicators of wtp for a variety of food attributes (e.g. Tranter et al 2009; Yiridoe et al 2005; Shaw \& Shiu 2002). 
Results

253

The consumer focus group findings can be summarised as: all participants bought free range eggs for perceived welfare benefits; participants had no idea that IP went on and were shocked to discover the fact, as they thought that free range production was the 'gold standard' for hen welfare; there was a general feeling of betrayal, with some indicating that they might stop buying free range eggs; and most participants said they would happily pay extra to compensate poultry farmers for the costs of removing or lessening the IP problem. In the main survey, only $3 \%$ of respondents reported that they did not buy eggs at all, most of whom kept their own chickens. The majority $(67 \%)$ of consumers reported that they bought eggs for their household and, also, did so weekly. The mean number of eggs bought monthly was 23 . Some $66 \%$ of the respondents reported that they always bought free range eggs, with a further $28 \%$ stating that they bought them sometimes; only $6 \%$ reported that they never bought free range eggs.

Respondents were asked why they bought free range eggs. They were given five possible reasons and asked to score each on a 6 point (0-5) Likert scale, with 5 being 'very important' and 0 being 'not important at all'. The most commonly given reason was: 'Hen welfare is better' which also had the highest mean importance score of 4.60 (S.D. 0.86). The next most commonly cited reason was: 'Free range hens are happy' with a mean importance score of 4.31 (S.D. 1.03). The next most commonly cited reason was: 'They taste better than other eggs' with a mean importance score of 3.67 (S.D. 1.51), followed by 'They are healthier than other eggs' (3.53; S.D. 1.52) and 'They are fresher than other eggs' (3.30; S.D. 1.68). 
276 Consumers were asked a series of questions designed to elicit their attitudes towards egg

277 laying hens and free range egg production. Their answers to the eight statements given,

278 showing their levels of agreement or disagreement, are shown in Table 1 below. Some $43 \%$

279 of respondents either agreed, or strongly agreed, with the statement that they were well-

280 informed about how laying hens were treated, with $78 \%$ expressing concern over the nature

281 of the treatment they received; $86 \%$ of respondents believed that free range production

282 offered 'higher levels of welfare than cage production', with $89 \%$ affirming that hens should

283 be able to display normal behaviour. In terms of the impact of production system on the

284 quality of eggs, 68\% thought that 'eggs from birds with a high welfare are healthier and

285 better tasting'. Furthermore, $41 \%$ of our respondents agreed with the statement that 'eggs

286 from hens with high welfare are safer to eat', in spite of a lack of scientific evidence to

287 support this view. Probably reflecting the highly positive views that respondents have of the

288 benefits of free range egg production, $76 \%$ said they were 'happy to pay more for free range

289 eggs'.

290

291 Table 1 around here

292

293 After the wtp questions, the respondents were asked whether, before reading the

294 questionnaire, they knew that IP was a common problem in all flocks of laying hens,

295 including free range. A minority (36\%) said that they were aware, while 64\% said they were

296 not. They were then asked whether knowing about IP changed their attitude towards free

297 range eggs: $40 \%$ said it did and $60 \%$ said that it did not.

298

299 The respondents were asked to rate, on a 100 point scale, how they perceived the welfare

300 level of free range hens compared to caged laying hens. Three base levels of welfare for 
caged hens were provided, at one of 40,50 or 60 points, with respondents being asked to rate the welfare of free range hens relative to these three base levels. Half of the respondents were asked this question before IP was explained to them and the other half after it had been explained. When respondents were asked to rate the welfare of free range hens after the phenomenon of IP had been explained to them, they gave a slightly lower mean welfare score (78.22) than those who had not yet had IP explained (78.76). In both cases, the respondents rated the welfare of free range production as significantly higher than cage production, although the difference between the two groups was non-significant (Table 2). However, there were some differences in respondents' mean welfare scores according to whether the baseline score they had on their questionnaires was 40, 50 or 60 . Higher 'mark-ups' for free range welfare were given for baselines of 40 and 50 compared to 60. From these responses, it can be taken that knowledge of pecking problems and the level of assumed welfare attributable to caged systems does not unduly impact consumer perceptions of the welfare premium that free range egg production provides over cage production.

Table 2 around here

To estimate wtp, Logistic Regression was carried out using backward stepwise regression, where variables were included in the regression model sequentially if their statistical significance was 0.1 or better and variables were retained in the model if their significance was 0.05 or better. Table 3 contains the two variables retained in the final model. From Table 3 , it can be seen that the respondents' socio-economic characteristics were not found to be significant determinants of wtp to reduce IP.

Table 3 around here 
327 To estimate wtp, the coefficients from Table 3 above were multiplied by the values of the relevant explanatory variables, for each respondent, as shown in Equation 1 above.

This gives a mean wtp estimate of 5.6 pence, i.e. the average respondent would be willing to pay a premium of 5.6 pence over the prevailing price of 6 medium-sized free range eggs to help poultry farmers ensure that hens do not suffer from IP. At the time of survey, the average current price of free range eggs was $£ 1.65$, so the estimated IP premium was $3.4 \%$ more.

It can be seen from Table 3 that only two of the variables tested were significant determinants of wtp: the bid level accepted and the attitudinal variable connected with the statement that respondents were happy to pay more for free range eggs. It is important to the credibility of such economic models that are used to estimate wtp that the bid level is a significant explanatory variable and that it has the expected sign (i.e. the higher the bid the less likely respondents are to say 'yes' to it). The positive sign on the attitudinal variable, indicates that the more strongly respondents agreed with the statement, the higher the bid level they were likely to accept in the wtp question.

It is common practice to identify and remove 'protest' bids from wtp estimation (these bids are often very high or very low, e.g. zero, depending on the context of the wtp questions; see Diamond et al, 1993). It is argued that these bids do not reflect the real value that respondents place on a good, but are posited in order to register an objection to having to pay by a particular payment vehicle, or for something originally available for free 'Debriefing' questions are used to identify such protest bids which may then be removed from the 
analyses. However, various researchers have questioned the often arbitrary nature of excluding protest bids from analyses (e.g. Jorensen et al, 1999) and the potential introduction of significant bias by doing so (see Halstead et al, 1992). In this study, there was no clear indication of protest bids from analysing responses to the debriefing question, so no observations were excluded from the estimation of wtp for that reason.

Table 4 presents responses to the debriefing questions. It will be seen that the most common reason given by respondents for their choices was a desire to pay more if it improves hen welfare (25.6\%), followed by a feeling that free range production is important for animal welfare (16.8\%). Some $15 \%$ of respondents felt that free range eggs were too expensive already, or that they could not afford to pay any more for their eggs.

\section{Table 4 around here}

\section{Discussion}

IP is found in a majority of egg-laying flocks in GB and is particularly prevalent in free range and non-cage systems. IP can have substantial welfare issues for hens and financial implications for producers. The results of this survey show that consumers are largely unaware of the welfare problems associated with IP in free range laying hens and are somewhat concerned when informed about such issues. Nonetheless, consumers seem to largely maintain their belief that free range production is superior on welfare and other grounds (such as food safety, health and taste) compared to other production systems. Respondents to the survey expressed a wtp price premium of $3.4 \%$ (5.6 pence) on the current retail price of eggs to help address IP in free range systems. This amount may be thought relatively small, perhaps because a number of respondents considered free range eggs 
to already be relatively expensive compared to cage eggs (and thus were not prepared to pay much more) and some were not convinced that paying more would help solve the problem (it could be argued that some in this latter category could be classed as protest bids). $\underline{\text { Indeed, a }}$ more rigorous identification of possible protest bids by the use of appropriate follow-up questions for this purpose could have resulted in some zero bids being removed from the sample with a subsequent increase in mean wtp. Moreover, it could also be argued that the framing of the wtp question in the context of the current egg prices at the time of survey and increased costs to farmers may have had a downward bias on respondents' wtp. Conversely though, one could maintain that this context merely served to ground the responses in reality. Over three per cent alseHowever, the wtp estimate appears credible when compared to the results of the Eurobarometer (2005) survey in the UK which found that most people would not pay more than $10 \%$ as an additional price premium to source eggs from an animal welfare friendly production system. However, around $£ 1.40$ per bird per year (assuming a mean yield of 25 dozen eggs per bird per year). This is a relatively substantial amount to producers given than an average gross margin per bird of around $£ 7$ might have been expected from free range egg enterprises at that time (Nix, 2013).

The finding that consumers have a positive wtp to improve animal welfare is consistent with other wtp consumer/citizen studies using various valuation methods. For example, Bennett et al (2012) (using choice experiment and CV methods) found that consumers in GB have a substantial wtp per annum to improve the welfare of various farmed species, whilst Bennett (1997) reported a consumer wtp of $£ 0.32$ per week to ban cage egg production in the UK (using the CV method) with the EC (2007) finding that $57 \%$ of EU consumers across 25 Member States were willing to pay a price premium for hens' eggs sourced from animal 

reported substantial mean wtp to improve the welfare of dairy cows, pigs, broilers and laying hens through legislation (also using the CV method) whilst Norwood and Lusk (2008) found that US consumers had a wtp for higher welfare in egg production (using an experimental auction-based approach) as did Carlsson et al (2005) in relation to consumers in Sweden (using a choice experiment method).

407

The CV method used for this study was considered appropriate by the authors. Alternative stated preference valuation methods include choice experiments and experimental auctions but these were not considered to be appropriate in this context. The choice experiment method is used to elicit the values that people have for a range of attributes and for different attribute levels associated with a good (see Louviere et al, 2000 for a comprehensive description). In this study, we wanted to elicit only one value in terms of consumers' wtp to help poultry farmers ensure that hens do not suffer from IP. Experimental auction approaches have the advantage that they use real goods, and real money, in an (experimental) market context as opposed to the hypothetical context used in CV (see Lusk and Shogren, 2007 for a comprehensive guide to experimental auctions). However, the cost of experimental auctions can be relatively quite high when a substantial number of consumers is involved. The price of eggs in food stores was also considered an appropriate payment vehicle for the study. Consumers are well used to a variety of shell eggs in food stores differentiated by size, breed, production system, price etc. It is difficult to be sure that there is not some hypothetical, or other bias, in our study which could have influenced the wtp estimates. We have tried to minimize these by sensible design of the survey instrument and by appropriate choice of analytical method. Moreover, as discussed above, the wtp results appear very credible and broadly consistent with people's stated attitudes and opinions. 
427 Conclusions and implications for animal welfare

428 The study reported here found that consumers are largely unaware of the problem of injurious

429 pecking in free range laying hens. Despite the finding that consumers have a belief that free 430 range means better welfare, there is a danger that this belief may be undermined if consumers

431 learn of significant welfare problems on free range units, such as those caused by IP on the 432 majority of free range egg production systems. Consumers were concerned when learning of 433 IP on free range units, with $40 \%$ stating that it changed their attitude towards free range eggs.

434 Producers need to address such welfare problems as a matter of urgency to ensure that 435 consumers continue to value free range egg production and that it can continue to command 436 its current price premium in the market. Indeed, the study findings suggest that there may be an additional price premium that producers could command, and that consumers would be willing to pay, for demonstrating the high welfare provenance of their eggs (e.g. birds with intact beaks and no, or limited, IP amongst other welfare attributes).

The findings of our study have relevance across livestock production systems (free range or otherwise) which consumers currently perceive as being high welfare. Consumers may feel equally concerned if they learn of other production practices or welfare issues of which they are unaware which could affect the demand for, and future sales of, free range eggs and other products in stores. Such practices and issues might include various animal mutilations such as beak trimming for chickens, castration and tail docking in pigs, lameness in dairy cows and in sheep, and leg health problems in broilers. Food retailers are keen to guard against such eventualities and have already put in place a number of initiatives to be able to demonstrate that they are addressing the issues. The livestock industries, and farm assurance 450 schemes, need also to take action to address such welfare issues to ensure that they are not 
vulnerable to large shifts in consumer demand as a result of changes in perceptions regarding

452 the welfare of animals used to produce our food.

453

454 There is also a wider issue concerning welfare provenance of livestock products and the 455 transparency of farm assurance. The FAWC (2006) recommended the development of a 456 single, accredited, mandatory EU-wide welfare-labelling scheme, backed by welfare 457 assessment based primarily on welfare outcomes, that would provide a transparent measure 458 of the welfare status of animals involved in producing livestock products. To date, such a 459 scheme has not been initiated, but it could greatly assist in assuring consumers about the 460 welfare provenance of the food they eat, provide a vehicle on which to base price premia for 461 differentiated livestock products, and so provide a stronger market incentive to producers to 462 improve farm animal welfare.

463

\section{Acknowledgements}

465 This article arises from a project (Reducing injurious pecking amongst layer hens by 466 implementing existing knowledge, 2007-12), supported by the Tubney Charitable Trust. We 467 are grateful for this support, but the opinions given here are ours and not necessarily those of 468 the Trust. 
Appendix 1. Specimen Questionnaire

Appendix 2. List of potential determining variables evaluated in the WTP analysis

\begin{tabular}{|c|c|c|}
\hline Variable name & Format & Description \\
\hline Employ & $\begin{array}{l}\text { Categorical variable } \\
\text { ( } 5 \text { categories) }\end{array}$ & Employment status \\
\hline Income & $\begin{array}{l}\text { Ordinal variable } \\
\text { (4 point scale) }\end{array}$ & $\begin{array}{l}\text { Household income category, values given as } \\
\text { central value in } 4 \text { categories }\end{array}$ \\
\hline Eggfreq & $\begin{array}{l}\text { Integer } \\
\text { (interval scale) }\end{array}$ & $\begin{array}{l}\text { Frequency of egg purchases, where } 1=\text { daily or } \\
\text { weekly; } 0=\text { less than weekly }\end{array}$ \\
\hline Rank_ch & $\begin{array}{l}\text { Integer } \\
\text { (ordinal scale } 0-100 \text { ) }\end{array}$ & $\begin{array}{l}\text { Difference between respondent welfare rating and } \\
\text { stated current average welfare rating }\end{array}$ \\
\hline A1 & $\begin{array}{l}\text { Binary variable } \\
(\mathrm{M} \text { or } \mathrm{F})\end{array}$ & Gender \\
\hline $\mathrm{A} 2$ & $\begin{array}{l}\text { Integer } \\
\text { (interval scale) }\end{array}$ & Respondent age \\
\hline A3 & $\begin{array}{l}\text { Integer } \\
\text { (interval scale) }\end{array}$ & Age left full-time education \\
\hline A8 & $\begin{array}{l}\text { Integer } \\
\text { (interval scale) }\end{array}$ & Number of eggs bought each month \\
\hline $\mathrm{A} 10 \mathrm{a}$ & $\begin{array}{l}\text { Ordinal variable } \\
\text { (5 point scale) }\end{array}$ & $\begin{array}{l}\text { Attitudinal variable. Ranking of agreement with } \\
\text { statement: 'They are fresher than other eggs' }\end{array}$ \\
\hline $\mathrm{A} 10 \mathrm{~b}$ & $\begin{array}{l}\text { Ordinal variable } \\
\text { (5 point scale) }\end{array}$ & $\begin{array}{l}\text { Attitudinal variable. Ranking of agreement with } \\
\text { statement: 'Free range hens are happy' }\end{array}$ \\
\hline $\mathrm{A} 10 \mathrm{c}$ & $\begin{array}{l}\text { Ordinal variable } \\
\text { (5 point scale) }\end{array}$ & $\begin{array}{l}\text { Attitudinal variable. Ranking of agreement with } \\
\text { statement: 'They taste better than other eggs' }\end{array}$ \\
\hline A10d & $\begin{array}{l}\text { Ordinal variable } \\
\text { (5 point scale) }\end{array}$ & $\begin{array}{l}\text { Attitudinal variable. Ranking of agreement with } \\
\text { statement: 'They are healthier than other eggs' }\end{array}$ \\
\hline $\mathrm{A} 10 \mathrm{e}$ & $\begin{array}{l}\text { Ordinal variable } \\
\text { ( } 5 \text { point scale) }\end{array}$ & $\begin{array}{l}\text { Attitudinal variable. Ranking of agreement with } \\
\text { statement: 'Hen welfare is better' }\end{array}$ \\
\hline B1 & $\begin{array}{l}\text { Binary variable } \\
(1=\text { agreement; } 0= \\
\text { neutral or } \\
\text { disagreement })\end{array}$ & $\begin{array}{l}\text { Attitudinal variable. Ranking of agreement with } \\
\text { statement: 'I feel well informed about how laying } \\
\text { hens are treated' }\end{array}$ \\
\hline B2 & $\begin{array}{l}\text { Binary variable } \\
(1=\text { agreement; } 0= \\
\text { neutral or } \\
\text { disagreement })\end{array}$ & $\begin{array}{l}\text { Attitudinal variable. Ranking of agreement with } \\
\text { statement: 'I am concerned about the way laying } \\
\text { hens are treated in the process of producing eggs' }\end{array}$ \\
\hline B3 & $\begin{array}{l}\text { Binary variable } \\
(1=\text { agreement; } 0= \\
\text { neutral or } \\
\text { disagreement })\end{array}$ & $\begin{array}{l}\text { Attitudinal variable. Ranking of agreement with } \\
\text { statement: 'Eggs from birds with high welfare are } \\
\text { healthier and better tasting' }\end{array}$ \\
\hline B4 & $\begin{array}{l}\text { Binary variable } \\
(1=\text { agreement; } 0= \\
\text { neutral or } \\
\text { disagreement })\end{array}$ & $\begin{array}{l}\text { Attitudinal variable. Ranking of agreement with } \\
\text { statement: 'It's wrong to eat eggs from hens that } \\
\text { have not had a good life' }\end{array}$ \\
\hline
\end{tabular}




\begin{tabular}{|c|c|c|}
\hline B5 & $\begin{array}{l}\text { Binary variable } \\
(1=\text { agreement; } 0= \\
\text { neutral or } \\
\text { disagreement })\end{array}$ & $\begin{array}{l}\text { Attitudinal variable. Ranking of agreement with } \\
\text { statement: 'Free range production provides higher } \\
\text { levels of welfare than cage production' }\end{array}$ \\
\hline B6 & $\begin{array}{l}\text { Binary variable } \\
(1=\text { agreement; } 0= \\
\text { neutral or } \\
\text { disagreement })\end{array}$ & $\begin{array}{l}\text { Attitudinal variable. Ranking of agreement with } \\
\text { statement: 'Eggs from high welfare are safer to } \\
\text { eat' }\end{array}$ \\
\hline B7 & $\begin{array}{l}\text { Binary variable } \\
(1=\text { agreement; } 0= \\
\text { neutral or } \\
\text { disagreement })\end{array}$ & $\begin{array}{l}\text { Attitudinal variable. Ranking of agreement with } \\
\text { statement: 'I am happy to pay more for free range } \\
\text { eggs' }\end{array}$ \\
\hline B8 & $\begin{array}{l}\text { Binary variable } \\
(1=\text { agreement; } 0= \\
\text { neutral or } \\
\text { disagreement })\end{array}$ & $\begin{array}{l}\text { Attitudinal variable. Ranking of agreement with } \\
\text { statement: 'It is important that hens can display } \\
\text { normal behaviour' }\end{array}$ \\
\hline $\mathrm{C} 1$ & $\begin{array}{l}\text { Integer } \\
\text { (interval scale) }\end{array}$ & Bid level accepted \\
\hline $\mathrm{C} 3$ & $\begin{array}{l}\text { Binary variable } \\
\text { (yes / no) }\end{array}$ & Prior knowledge of feather pecking as a problem \\
\hline $\mathrm{C5a}$ & $\begin{array}{l}\text { Binary variable } \\
\text { (yes / no) }\end{array}$ & $\begin{array}{l}\text { Knowledge of feather pecking changes attitudes } \\
\text { to free range eggs }\end{array}$ \\
\hline
\end{tabular}


References

476

477

Bennett RM 1997 Farm animal welfare and food policy. Food Policy 22: 281-288

478

Bennett RM and Blaney RJP 2003 Estimating the benefits of farm animal welfare

legislation using the contingent valuation method. Agricultural Economics 29: 85-98

481

482

Bennett RM and Larson D 1996 Contingent valuation of the perceived benefits of farm

animal welfare legislation: an exploratory survey. Journal of Agricultural Economics 47:

224-235

485

486

487

Bennett R, Kehlbacher A and Balcombe K 2012 A method for the economic valuation of animal welfare benefits using a single welfare score. Animal Welfare 21: 125-130

488 laying hens. EFSA Journal 197: 1-23

492 Journal 63: 101-114

497

Burgess D and Hutchinson WG 2005 Do people value the welfare of farm animals? 
501 Cameron TA 1988 A new paradigm for valuing non-market goods using referendum data:

502

503

504

505

506

507

508

509

510

511

512

513

514

515

516

517

518

519

520

521

522

523

maximum likelihood estimation by censored logistic regression. Journal of Environmental

Economics and Management 15: 355-379

Carlsson F, Frykblom P and Lagerkvist CJ 2005 Consumer preferences for food product quality attributes from Swedish agriculture. Ambio 34: 366-370

Craig JV and Lee HY 1990 Beak trimming and genetic stock effects on behaviour and mortality from cannibalism in white leghorn-type pullets. Applied Animal Behaviour Science 25: $107-123$

Damme K 1999 Effect of beak-trimming and strain on performance, feather loss and nesting behaviour of different commercial white layer hybrids in floor pens. Archiv Fur Geflugelkunde 63: 93-99

Defra 2014 United Kingdom Egg Statistics - Quarter 4, 2013. 6 February 2014. Defra: London, UK

Dennis RL, Fahey AG and Cheng, HW 2009 Infrared beak treatment method compared with conventional hot-blade trimming in laying hens. Poultry Science 88: 38-43

EC 2007 Attitudes of consumers towards the welfare of farmed animals. Wave 2. Special Eurobarometer. 
El-Lethey H, Aerni V, Jungi TW and Wechsler B 2000 Stress and feather pecking in laying hens in relation to housing conditions. British Poultry Science 41: 22-28

529

530

Eurobarometer 2005 Attitudes of consumers towards the welfare of farmed animals. Special

Eurobarometer 229. European Commission: Luxembourg

532

Eurobarometer 2007 Attitudes of EU citizens towards animal welfare. Special

Eurobarometer 270. European Commission: Luxembourg

535

536

FAWC 2006 Report on Welfare Labelling. Farm Animal Welfare Council, London.

537

Fossum O, Jansson DS, Etterlin PE and Vagsholm I 2009 Causes of mortality in laying hens in different housing systems in 2001 to 2004. Acta Veterinaria Scandinavica 51: article

541

542

Gentle MJ, Waddington D, Hunter LN and Jones RB 1990 Behavioural evidence for

543 persistent pain following partial beak amputation in chickens. Applied Animal Behaviour Science 27: 149-157

545

Green LE, Lewis K, Kimpton A and Nicol CJ 2000 Cross-sectional study of the prevalence 547 of feather pecking in laying hens in alternative systems and its associations with management 548 and disease. Veterinary Record 147: 233-238 
550 Gunnarsson S, Keeling LJ and Svedberg J 1999 Effect of rearing factors on the prevalence

551 of floor eggs, cloacal cannibalism and feather pecking in commercial flocks of loose housed 552 laying hens. British Poultry Science 40: 12-18

553

554

Halstead JM, Luloff AE and Stevens TH 1992 Protest bidders in contingent valuation.

Northeastern Journal of Agricultural and Resource Economics 21 (2)

556

557

558

Hanemann M, Loomis J and Kanninen B 1991 Statistical efficiency of double-bounded dichotomous choice contingent valuation. American Journal of Agricultural Economics 73:

559 $1255-1263$

560

561

562

Huber-Eicher B 1999 A survey of layer-type pullet rearing in Switzerland. World's Poultry Science Journal 55: 83-91

563

564

565

commercial flocks of laying hens. Applied Animal Behaviour Science 74: 223-231

566

567

568

Hughes BO 1973 The effect of implanted hormones on feather pecking and cannibalism in pullets. British Poultry Science 14: 341-348

569

570 Hughes BO and Duncan IJ 1972 The influence of strain and environmental factors upon

571 feather pecking and cannibalism in fowls. British Poultry Science 13: 525-547

572 
573 Hughes BO and Gentle MJ 1995 Beak trimming in poultry, its implications for welfare.

574 World's Poultry Science Journal 51: 51-61

575

576 IGD 2011 Shopper attitudes to animal welfare. A report for Freedom Food by IGD

577 http://www.freedomfoodpublishing.co.uk/fairerlife/downloads/Shopper_Attitudes_Welfare

$578 \quad$ Report.pdf

579

580

Jorgensen B, Syme G, Bishop B and Nancarrow B 1999 Protest responses in contingent

581

valuation. Environmental and Resource Economics 14 (1): 131-150

582

583

Kaplowitz MD, Hadlock TD and Levine R 2004 A comparison of web and mail survey

584

response rates. Public Opinion Quarterly 68 (1): 94-101

585

586

Keeling LJ and Jensen P 1995 Do feather pecking and cannibalistic hens have different

587

personalities? Applied Animal Behaviour Science 44: 265

588

589

Lambton SL, Knowles TG, Yorke C and Nicol CJ 2010 The risk factors affecting the 590

development of gentle and severe feather pecking in loose housed laying hens. Applied

591

Animal Behaviour Science 123: 32-42

592

593

Lambton SL, Nicol CJ, Friel M, Main DCJ, McKinstry JL, Sherwin CM, Walton J and

594

Weeks CA 2013 A bespoke management package can reduce levels on injurious pecking in

595 loose-housed laying hen flocks. Veterinary Record 172: 423

596 
Louviere JL, Hensher DA and Swait JD 2000 Stated Choice Methods. Cambridge

598

University Press: Cambridge, UK

599

600

601

Lusk JL and Shogren JF 2007 Experimental auctions. Methods and applications in economic and marketing research. Cambridge University Press: Cambridge, UK

602

603

Marsden PV and Wright JD (eds) 2010 Handbook of Survey Research. 2nd edition.

604

Emerald Group Publishing Ltd: Bingley, UK

605

606

607

608

609

International Journal of Sociology of Food and Agriculture 15: 59-73

610

611

612

McKeegan DEF and Savory CJ 1999 Behavioural and hormonal changes associated with sexual maturity in layer pullets. British Poultry Science 39: S6-S7

613

614

615

Mitchell RC and Carson RT 1989 Using Surveys to Value Public Goods. The Contingent

Valuation Method. Resources for the Future. Washington DC

616

617

Nicol CJ, Gregory NG, Knowles TG, Parkman ID and Wilkins LJ 1999 Differential

618

effects of increased stocking density, mediated by increased flock size, on feather pecking

619

and aggression in laying hens. Applied Animal Behaviour Science 65: 137-152

620 
Weeks, CA and Rodenburg TB 2013 The prevention and control of feather pecking:

624

Nix J 2013 Farm Management Pocketbook. 44th edition 2014. Agro Business Consultants Ltd: Melton Mowbray, Leicestershire, UK (p 94)

627

Norgaard-Nielsen G, Vestergaard K and Simonsen HB 1993 Effects of rearing experience and stimulus enrichment on feather damage in laying hens. Applied Animal Behaviour

631

Norwood FB and Lusk JL 2008 A calibrated auction-conjoint valuation method: valuing pork and eggs produced under differing animal welfare conditions. Working Paper. Department of Agricultural Economics, Oklahoma State University

635

Office of National Statistics 2013 UK Population Census 2011. TSO: London

637

638

Peguri A and Coon C 1993 Effect of feather coverage and temperature on layer

639 performance. Poultry Science 72: 1318-1329

640

Pötzsch CJ, Lewis K, Nicol CJ and Green LE 2001 A cross-sectional study of the 642 prevalence of vent pecking in laying hens in alternative systems and its associations with feather pecking, management and disease. Applied Animal Behaviour Science 74: 259-272 
Welfare assessment of laying hens in furnished cages and non-cage systems: an on-farm comparison. Animal Welfare 17: 363-373

648

Rodenburg TB, van Krimpen MM, de Jong IC, de Haas EN, Kops MS, Riedstra BJ,

Nordquist RE, Wagenaar JP, Bestman M and Nichol CJ 2013 The prevention and control 651 of feather pecking in laying hens: identifying the underlying principles. World's Poultry Science Journal 69: 361-374

653 York, USA

656

657

Schafer JL 1997 Analysis of incomplete multivariate data. Chapman \& Hall: London, UK

658 of Consumer Studies 26: 286-293

662

Sherwin CM, Richards GJ and Nicol CJ 2010 Comparison of the welfare of layer hens in 4 664 housing systems in the UK. British Poultry Science 51: 488-499

665

666

Staack M, Gruber B, Keppler C, Zaludik K, Niebuhr K and Knierim U 2007 Importance

667 of the rearing period for laying hens in alternative systems. Deutsche Tierarztliche

668 Wochenschrift 114: 86-90

669 
670 Tauson R and Svensson SA 1980 Influence of plumage condition on the hens feed

671 requirement. Swedish Journal of Agricultural Research 10: 35-39

672

673 Tranter RB, Bennett RM, Costa L, Cowan C, Holt GC, Jones PJ, Miele M, Sottomayor

674 M and Vestergaard J 2009 Consumers' willingness-to-pay for organic conversion-grade 675 food: evidence from five EU countries. Food Policy 34: 287-294

676

677 Weeks CA, Brown SN, Richards GJ, Wilkins LJ and Knowles TG 2012 Levels of 678 mortality in hens by end of lay on farm and in transit to slaughter in Great Britain. Veterinary 679 Record 170: 647

680

681 Yiridoe EK, Bonti-Ankomah S and Martin RC 2005 Comparison of consumer perceptions 682 and preference toward organic versus conventionally produced foods: a review and update of 683 the literature. Renewable Agriculture and Food Systems 20: 193-205

684 
Table 1. Respondents' levels of agreement/disagreement with a series of statements

\begin{tabular}{|c|c|c|c|c|c|}
\hline $\begin{array}{l}\text { Statements on egg production and hen } \\
\text { welfare }\end{array}$ & $\begin{array}{l}\text { Strongly } \\
\text { agree }\end{array}$ & Agree & $\begin{array}{c}\text { Neither } \\
\text { agree/ } \\
\text { disagree }\end{array}$ & Disagree & $\begin{array}{l}\text { Strongly } \\
\text { disagree }\end{array}$ \\
\hline $\begin{array}{l}\text { I feel well-informed about how laying hens } \\
\text { are treated in egg production }\end{array}$ & 8 & 35 & 32 & 20 & 5 \\
\hline $\begin{array}{l}\text { I am concerned about the way laying hens } \\
\text { are treated in the process of producing eggs }\end{array}$ & 35 & 43 & 20 & 1 & 1 \\
\hline $\begin{array}{l}\text { Eggs from birds with high welfare are } \\
\text { healthier and better tasting }\end{array}$ & 22 & 46 & 27 & 3 & 2 \\
\hline $\begin{array}{l}\text { It is wrong to eat eggs from hens that have } \\
\text { not had a good life }\end{array}$ & 33 & 31 & 26 & 8 & 2 \\
\hline $\begin{array}{l}\text { Free range production provides higher } \\
\text { levels of welfare than cage production }\end{array}$ & 40 & 46 & 12 & 2 & 0 \\
\hline $\begin{array}{l}\text { Eggs from hens with high welfare are safer } \\
\text { to eat }\end{array}$ & 15 & 26 & 47 & 11 & 1 \\
\hline I am happy to pay more for free range eggs & 29 & 47 & 15 & 7 & 2 \\
\hline $\begin{array}{l}\text { It is important that hens can display normal } \\
\text { behaviour }\end{array}$ & 46 & 43 & 10 & 1 & 0 \\
\hline
\end{tabular}



informed about IP on the questionnaire.

693

Respondents' welfare scores for free range egg laying hens

\begin{tabular}{cccc}
\hline $\begin{array}{c}\text { Arbitrary cage } \\
\text { welfare score }\end{array}$ & $\begin{array}{c}\text { Question posed before IP } \\
\text { explained (n) }\end{array}$ & $\begin{array}{c}\text { Question posed after } \\
\text { IP explained (n) }\end{array}$ & $\begin{array}{c}\text { Overall } \\
(\mathrm{n})\end{array}$ \\
\hline 40 & $74.32(44)$ & $72.7(42)$ & $73.53(86)$ \\
50 & $78.56(39)$ & $79.34(50)$ & $79.00(89)$ \\
60 & $85.32(31)$ & $82.63(40)$ & $83.80(71)$ \\
\hline Overall & $78.76(114)$ & $78.22(132)$ & -
\end{tabular}

694

695 
Table 3. Logistic Regression estimates and their statistical significance

697

\begin{tabular}{llcc}
\hline $\begin{array}{l}\text { Variable } \\
\text { name }\end{array}$ & \multicolumn{1}{c}{ Description } & $\begin{array}{c}\text { Maximum likelihood } \\
\text { estimate }\end{array}$ & Pr>ChiSq \\
\hline Intercept & \multicolumn{1}{c}{-3.8761} & 0.0004 \\
C1 & Bid level accepted & 0.0937 & 0.0002 \\
B7 & Attitudinal variable. Ranking of agreement & 0.8458 & 0.0012 \\
& $\begin{array}{l}\text { on a 5-point scale where 1=agreement and } \\
\text { 0=neutral or disagreement with statement: }\end{array}$ & & \\
& $\begin{array}{l}\text { 'I am happy to pay more for free range } \\
\text { eggs' }\end{array}$ & & \\
\hline
\end{tabular}

698

699 Notes:

$700 \quad-2$ Log likelihood (with covariates) 239.24.

701 Chi-Square for covariates 54.7 with 27 degrees of freedom $(p=<0.0003)$.

702

Association of predicted probabilities and observed responses $=75 \%$ concordant.

703

704 
705 Table 4. Answers to debriefing questions ${ }^{1}$ as to why consumers indicated that they

706 might pay more to reduce levels of IP in free range flocks (\% of 193 responses)

\section{Reasons}

Will pay more if it improves welfare/the hens have a better life

Insist on free range for welfare reasons/animal welfare is very important

Too expensive already/can't afford to pay any more

Miscellaneous reasons

No answer given at all

Price premium must benefit farmer only

Will the measures to reduce IP really work

All birds peck each other at times

${ }^{1}$ No respondent gave what could be construed as a protest bid. 